
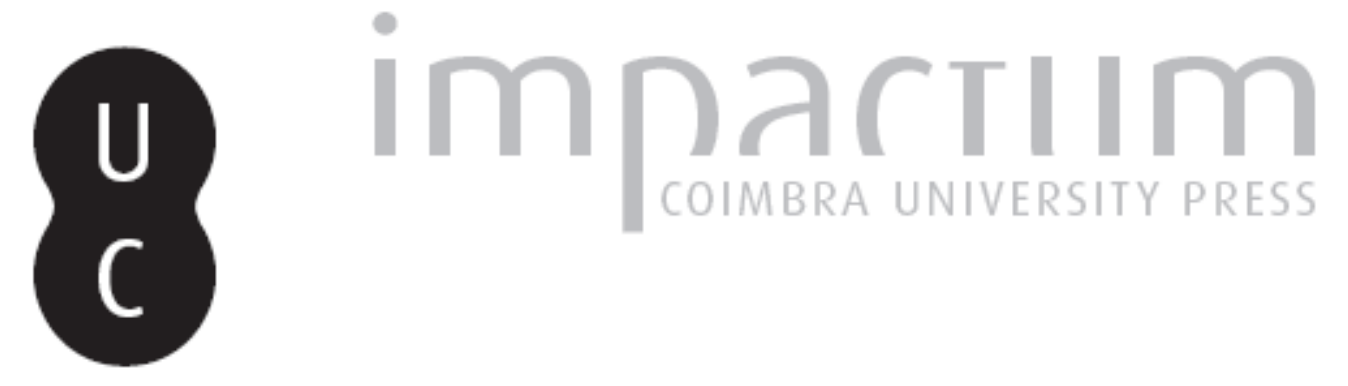

A representação do discurso jornalístico na literatura de José Saramago

Autor(es): $\quad$ Alves, Daniel Vechio

Publicado por: Imprensa da Universidade de Coimbra

URL persistente:

URI:http://hdl.handle.net/10316.2/39640

DOI:

DOI:http://dx.doi.org/10.14195/2183-5462_29_14

Accessed : $\quad$ 26-Apr-2023 13:52:19

A navegação consulta e descarregamento dos títulos inseridos nas Bibliotecas Digitais UC Digitalis, UC Pombalina e UC Impactum, pressupõem a aceitação plena e sem reservas dos Termos e Condições de Uso destas Bibliotecas Digitais, disponíveis em https://digitalis.uc.pt/pt-pt/termos.

Conforme exposto nos referidos Termos e Condições de Uso, o descarregamento de títulos de acesso restrito requer uma licença válida de autorização devendo o utilizador aceder ao(s) documento(s) a partir de um endereço de IP da instituição detentora da supramencionada licença.

Ao utilizador é apenas permitido o descarregamento para uso pessoal, pelo que o emprego do(s) título(s) descarregado(s) para outro fim, designadamente comercial, carece de autorização do respetivo autor ou editor da obra.

Na medida em que todas as obras da UC Digitalis se encontram protegidas pelo Código do Direito de Autor e Direitos Conexos e demais legislação aplicável, toda a cópia, parcial ou total, deste documento, nos casos em que é legalmente admitida, deverá conter ou fazer-se acompanhar por este aviso. 


\section{Media Jornalismo}

\section{MÉDIA E COLONIALISMO(S)}




\section{A REPRESENTAÇÃO DO DISCURSO JORNALÍSTICO NA LITERATURA DE JOSÉ SARAMAGO}

\section{THE JOURNALISTIC DISCOURSE REPRESENTATION IN SARAMAGO'S LITERATURE}

\section{DANIEL VECCHIO ALVES}

UNIVERSIDADE ESTADUAL DE CAMPINAS, INSTITUTO DE FILOSOFIA E CIÊNCIAS

HUMANAS, PROGRAMA DOUTORAL EM HISTÓRIA CULTURAL

SÃO PAULO CEP 13083-896 BRASIL

DANIELVECCHIOALVES@HOTMAIL.COM

\section{Resumo}

Pouco se fala sobre os intertextos literários do discurso jornalístico que se fazem presentes no romance português. Perpassando pela natureza dos poderes político-económicos que estão por trás dos instrumentos da comunicação, nossa atenção especial será dada à análise dos romances 0 ano da morte de Ricardo Reis e $A$ jangada de pedra de José Saramago, de modo a enfatizar, respectivamente, o cenário do jornalismo impresso na Lisboa salazarista da década de 1930 e o jornalismo radiotelevisivo da década de 1980 . Observaremos nesse artigo que, com a leitura desses dois romances, fica claro que ambas as fases do jornalismo português , antes e depois da revolução democrática do 25 de abril, sofrem um processo de interferência contínua de manipulação e dissimulação das notícias, o que contribuiu para proliferar no discurso da imprensa de certo "irrealismo", nos preceitos de Eduardo Lourenço. Realizaremos, por fim, uma abordagem mais esclarecedora acerca desse irrealismo cultural constituído por muitas décadas de dissimulação comunicativa, evidenciando os processos literários através dos quais o discurso manipulador da mídia é representado. Tais processos serão reconhecidos no texto saramaguiano pela intertextualidade, em seu aspecto central, e pelos processos de alegoria e dialogismo.

\section{Palavras-chave}

União Europeia; Portugal; Salazarismo; Romance; Jornalismo.

\section{Abstract}

Very little is said about literary intertexts of journalistic discourse that are present in the Portuguese novel. Permeating the nature of political and economic powers behind of the communication's instruments, our special attention will be given to the analysis of the novels 0 ano da morte de Ricardo Ricardo Reis and A jangada de pedra. We argue that these texts were written by José Saramago in order to explore the print journalism's set in Salazar's Lisbon of the 1930s and the telejournalism's set of the 1980s. Based in this reading, we will observe in this article that 
the journalistic discourse still suffers a brutal interference process of manipulation, which contributed to proliferate certain fictional vision among the people, even after the drop of the dictatorship of Salazar in the 1970s. We will release, finally, a more insightful approach about this discursive unreality consisting of many decades of communicative dissimulation, highlighting some literary processes by which the manipulative discourse of journalism is represented. Such processes will be recognized in the Saramago's text by the intertextuality, in its central aspect, besides the allegory processes and the dialogism.

\section{KEYWORDS}

European Union; Portugal; Salazarism; Romance; Journalism.

...falemos abertamente sobre o que foi a nossa vida, se era vida aquilo, durante o tempo em que estivemos cegos, que os jornais recordem, que os escritores escrevam, que a televisão mostre as imagens da cidade tomada depois de termos recuperado a visão, convençam-se as pessoas a falar dos males de toda a espécie que tiveram de suportar, falem dos mortos, dos desaparecidos, das ruínas, dos incêndios, do lixo, da podridão, e depois, quando tivermos arrancado os farrapos de falsa normalidade com que temos andado a querer rapar a chaga, diremos que a cegueira desses dias regressou sob uma nova forma, [...]. (Saramago, 2004, p. 175)

Nos muitos romances produzidos depois da Revolução dos Cravos, em 1974, ressalta-se um papel revisionista sobre a história nacional. Essa reelaboração torna-se latente entre os romancistas portugueses contemporâneos por compartilharem a ideia de que "nenhum regime totalitário dá azo a que se faça História como deve ser. Todos eles necessitam, em maior ou menor grau, de ocultações e de mitificações" (Lepecki, 1988, p. 388-389) que precisam ser ponderadas em qualquer abordagem feita sobre o passado.

Essa perspectiva retoma o problema do "discurso" nos termos de Benveniste (1976), no qual o caráter intencional e 0 direito da linguagem ao ato encontra um ponto de apoio: é no discurso como ato transitório ou temporal que encontramos a mediação entre o mundo, 0 outro e 0 sujeito. Os sentidos discursivos não estão vinculados a signos isolados, senão numa operação complexa que constitui 0 ato predicativo e configurativo da linguagem.

Partindo de tais perspetivas, o presente artigo tomará o discurso como uma instância textual que visa não somente sua capacidade referencial, mas as escolhas efetuadas pelo autor do discurso, localizando nessas escolhas as forças que operam na representação do mundo e da sociedade. Assim, não pretendemos abordar o significado dos signos de um a um como pretende uma análise semiótica, mas seu significado interativo ou frasal através da formação discursiva mencionada.

Esse procedimento é justificado pelo fato de que o jornalismo "comporta por natureza poderes escondidos atrás dos instrumentos textuais que utiliza, tanto que sua actividade editorial não era e ainda não é relativamente independente do poder político e das preocupações econômicas." (Le Goff, 1999: 19). Com isso averiguaremos que a jornalística como literatura torna-se um espaço textual em potencial para dar corpo a muitas dessas nuances ideológicas e semânticas do discurso jor- 
nalístico, reconhecimento poético que nos levou ao objetivo central desse trabalho que é estudar os intertextos literários embasados nos subterfúgios noticiosos que ganham espaço nas obras romanescas de José Saramago.

Nossa atenção especial será dada à análise dos romances 0 ano da morte de Ricardo Reis (1984) e A jangada de pedra (1986), que comportam, respectivamente, o cenário do jornalismo impresso na Lisboa salazarista da década de 1930 e o jornalismo radiofônico e televisivo da década de 1980. Cronista, crítico literário, poeta e homem experiente na área da edição, Saramago foi colunista e diretor-adjunto do jornal Diário de Notícias'.

É no mínimo estranho o porquê de ainda haver pouca pesquisa feita sobre tais intertextos, visto que Saramago atuou no meio jornalístico durate alguns anos, sendo ao mesmo tempo um escritor de projeção nacional e internacional ${ }^{2}$. Os trabaIhos a respeito de suas obra, em sua maior parte, tratam do caráter memorialístico ou autobiográfico da sua narrativa, não entrando propriamente nesse intertexto.

Apesar de ter proporcionado uma vasta colaboração aos jornais, seja como editorialista, crítico literário e até diretor-adjunto, "José Saramago nunca se considerou um jornalista. [...]. No entanto, ele passa por diversos jornais emblemáticos do panorama mediático português e, também, chega à direção de um dos periódicos mais respeitados na época: o Diário de Notícias." (Aguiar, 2014:1).

De qualquer forma, José Saramago não foi jornalista na acepção total do termo. Nos dois anos em que esteve no Diário, por exemplo, não era incumbido oficialmente pelas atividades de repórter nem mesmo a redigir notícias:

O seu trabalho foi comentar a atualidade e deixar para os historiadores do futuro um conjunto precioso de editoriais magistralmente escritos e jornalisticamente rigorosos. Textos que estão publicados em livro sob o título «As Opiniões que o DL Teve» e que enobrecem o jornalismo português. (Gonçalves, 2010: s/p)

Saramago iniciou-se na publicação de crônicas no jornal A Capital, em 1968, e no Jornal do Fundão, em 1971. A partir de 1972, começou a colaborar no Diário como cronista e editorialista. Por isso, cabe inferirmos que nessa passagem pelo jornalismo, ele já estava plenamente imerso no mundo da imprensa, o que nos faz inferir que seu trabalho "não se tratava de garantir apenas crônicas semanais e periódicas, mas de ter que trabalhar profissionalmente no seio de uma equipe de jornalistas, contribuindo de muitas formas para a redação dos textos que deveriam nortear a linha editorial." (Lopes, 2010: 61).

Além disso, ele começava a se afirmar no panorama cultural português com publicações várias, recebendo críticas positivas principalmente pelas coletâneas

1 “[... ] o DN era provavelmente o jornal mais proeminente do país, tendo uma tiragem acima dos 100 mil exemplares. A ala revolucionária produzia então uma situação inesperada em que o governo, as Forças Armadas, muitas empresas e até entidades como a Rádio Renascença ou a Fundação Calouste Gulbenkian eram postulados a serviço da classe operária e do socialismo. E o DN não foi exceção." (LOPES, 2010: 75).

2 Dentre alguns poucos estudos, ver Saulo Gomes Thimóteo, 0 'ars poetica' saramaguiano ou 0 cultivo da palavra (Nau Literária, v. 6, n. 1, 2010, pp. 1-13), e Marta Cristina S. Aguiar, José Saramago e os jornais: os anos de 1968 a 1975 (Dissertação da ESCS, Lisboa, 2014). 
de crônicas. Contudo, é preciso dizer que, apesar de Saramago crescer como cronista e editor, ele jamais deixaria de lado os cruzamentos do discurso jornalístico com a escrita literária, mesmo depois de enveredar completamente pelo romance.

Na verdade, em muitas crônicas "já encontramos elementos de imaginação poética e ficcional, além do engajamento social e político" (Thimóteo, 2010,: 1), obtendo no romance um material mais refinado e diferenciado em que tais imaginários, expressões e maneiras pelas quais o escritor tece os comentários são assimilados na concepção moderna do discurso (Benveniste, 1976):

Saramago usa essa crítica velada para mostrar como as palavras, aquelas que tantas coisas podem ser, são usadas nos discursos para, intencionalmente, praticar uma ação particular, seja ela apagar um defeito (com as "cortinas de fumo"), seja adornar uma qualidade (com as "bambinelas de veludo"). Assim, o cronista vai entretecendo essas paredes que se chamam discursos, mostrando ao seu leitor as suas intenções (Thimóteo, 2010, p. 5)

Claro que suas crônicas são naturalmente mais comprometidascom a atualidade e incorporam uma dose bem mais reduzida de imaginação em comparação a sua obra literária. Porém, veremos no seu devido momento que seus textos jornalísticos são matéria-prima para a constituição de certos imaginários e outras subjetividades que compõem cenas variadas dos dois mencionados romances.

Antes de abordar tais aspectos, contudo, devemos primeiro reconhecer o terreno textual configurativo da crónica e, nesse reconhecimeto, ressaltamos que, nela, é explícita a pretensão em utilizar o espaço midiático como ferramenta política, visando a desconstrução das dissimulações políticas do governo português, bem como do jornalismo conservador de Portugal e da Europa.

Na verdade:

o seu trabalho na imprensa pode ser dividido em duas fases, coincidindo com dois momentos históricos diferentes. A primeira fase, nos jornais A Capital e no Jornal do Fundão, ocorre durante o marcelismo. Aqui, de 1968 a 1972, escreveu sobre as suas memórias, onde inclui as viagens que fez, e sobre temas soltos. Porém, também escreveu sobre política num momento em que, apesar do desaparecimento político de Salazar, a ditadura teimava em persistir. [...]. A segunda fase, que coincide com a desagregação da ditadura e os momentos mais agitados da Revolução, é ainda mais complexa. Aqui, o trabalho de Saramago assume feições diferentes das que revelou n'A Capital e no Jornal do Fundão. Cronista e editorialista do Diário de Lisboa (1972-1973) e do Diário de Notícias (1975), Saramago envereda abertamente por um jornalismo interventivo, político, e não hesita em abordar temas relacionados com o contexto político-social da época. A sua experiência no DN é ainda marcada pelo polémico episódio que culminou no despedimento de 24 jornalistas. (Aguiar, 2014: 1-2)

Essa mudança, sem dúvida, proporcionou a muitos de seus leitores um olhar mais crítico sobre a política e a economia do país, aumentando o impacto social do seu jornalismo: 
Ao proclamar que todos um dia faríamos jornais, o que eu tentei foi exprimir uma espécie de aspiração cívica, evidentemente utópica, segundo o qual o direito de informar e de ser informado se regeria por exclusivos ditames de verdade e de dignidade, sem cedências ou contemporizações com qualquer forma de poder. Não estaríamos a salvo do erro, porém justificar-nos-ia a boa fé. (Saramago, 2014: 3-4)

Com essa passagem, podemos supor o grau de importância da carreira de Saramago no jornalismo para o sensibilizar cada vez mais para a construção do fato e para a fabricação dos discursos sobre inúmeras coisas e pessoas, reavaliando a história política e jornalística de uma nação afundada em notícias censuradas e dissimuladas. Essa estratégia foi levada tão a fundo que, "no seu livro Os Apontamentos, Saramago revela que muitas das suas crônicas não foram publicadas, por terem sido vítimas da censura à imprensa que vigorava na época." (Aguiar, 2014: 4).

Tal episódio nos evidencia o panorama opressivo do jornalismo, corroborando 0 que diz Estrela Serrano ao afirmar que o discurso da imprensa "fornece elementos úteis para 0 estudo das relações entre 0 jornalismo e a política. A maior parte de seu arquivo permite constatar a existência de uma visão normativa e instrumental do jornalismo, à semelhança do que [...] acontece noutros países." (Serrano, 2006: 70).

Para justificar essa inerência política do discurso jornalítico, ressaltamos que desde 0 século XIX, na Europa, há partidos que são proprietários de jornais, o que favoreceu desde então uma intrincada relação entre políticos e jornalistas. Isso nos leva, inevitavelmente, a considerar os jornalistas como atores políticos e 0 jornalismo como uma instituição política. 0 poder da imprensa residia, assim, na capacidade de dar expressão simbólica e pública aos mecanismos de poder.

Amplia-se esse cenário midiático nas duas últimas décadas do século XIX, a exemplo do jornal 0 Século que foi fundado em finais de 1880, no contexto das comemorações do tricentenário da morte de Camões. Trata-se de um veículo informativo que terá longa existência e que se empenhará, desde sua fase inicial, na defesa e afirmação dos projetos governamentais.

Ademais, o jornalismo foi e é um poderoso instrumento político que perdura até hoje, sendo uma ameaça constante à própria democracia ao promover a desinformação através de uma linha tendenciosa de notícias que atende estritamente aos interesses políticos e empresariais (Ribeiro, 2012). Ou seja, ao longo do século XX, mesmo com o ofício de jornalista "transformando-se numa profissão [...] à procura de um espaço autónomo de legitimação" (Guimarães; Fernandes, 2012: 4) por meio de uma classe profissional com direitos, deveres e competências específicas, essa situação ainda parece estar longe de ser superada.

Nesse sentido, cabe apontar que a história do jornalismo em Portugal e no mundo é inseparável da própria história cultural e política, sendo esse fator cada vez mais determinante nos rumos da sociedade. 0 exercício do jornalismo português durante 0 século XX, é exemplo de uma atividade intelectual oprimida principalmente por causa da censura ativa do regime ditatorial (1926-1974), autoproclamado Estado Novo desde a Constituiç̧ão de 1933. Durante a ditadura salazarista, a presença da censura política e religiosa com o exercício do exame prévio, o fechamento de jornais e a quase ausência de um espaço público de discussão revela o controle e 
a manipulação não só dos jornais, mas dos meios de comunicação e, consequentemente, dos meios de transmissão de saber.

Isso inclui todas as formas de criação e acesso à informação como livros, editoras, emissoras de rádio, espetáculos, artes plásticas, música, ensino escolar e universitário, cinema e, mais tarde, a televisão. Todos estavam sob o olhar dos censores e sob ameaça da polícia secreta. 0 efeito disso é que a informação jornalística nacional era praticamente uma agenda do governo, com um discurso oficioso e protocolar ${ }^{3}$.

Como resultado dessa política de controle informativo, só quem fosse de confiança e tivesse aliança política com o governo podia administrar um jornal. Tais alianças foram estreitadas por António de Oliveira Salazar, que via com importância o papel da comunicação na sociedade, razão que o levou a criar o Secretariado da Propaganda Nacional em 1933: "O SPN estava sob a estrita dependência de Salazar e teve 0 seu apogeu entre os anos 30 a 40." (Silva, 2009: 3113).

Consequentemente, nesses espaços vigiados da comunicação não se discutia Deus, pátria e sua história, não se discutia a autoridade, a família e a sua moral. Essas eram verdades insofismáveis, pois, para Salazar, nelas se assentavam os pilares que permitiriam a construção de um Estado com autoridade prestigiada e com sentimento patriótico.

Não havia uma ação pública que não estivesse enquadrada dentro desses paradigmas do regime. 0 medo de ser rechaçado pela própria população, de ser denunciado e ir preso eram constantes. A PIDE, a polícia secreta de Salazar, tinha informantes em todos os lugares, por isso não se ousava levantar a voz para dizer mal do governo em nenhum lugar. Para piorar, a censura era manejada "por militares pouco cultos e pouco instruídos" (Castelhano; Prata, et al, 2006: 12).

É partindo desse panorama opressivo e noticioso que vamos observar a difusão e a desconstrução do discurso jornalístico em 0 ano da morte de Ricardo Reis e $A$ jangada de pedra de José Saramago. Com a análise de tais romances, ficará claro que o jornalismo português sofreu um processo de interferência contínua de manipulação política, o que contribuiu para sacramentar o que chamamos aqui de irrealismo jornalístico, nos preceitos de Eduardo Lourenço (1989).

Com o tratamento literário desse irrealismo nas obras mencionadas, se denuncia criticamente a perduração de um jornalismo conservador dissimulado na ideia de fato e de desenvolvimento econômico, mesmo depois da queda da ditadura salazarista quando vigoram os preceitos de liberdade de expressão e de imprensa. Tal continuidade corrobora a tese de Eduardo Lourenço que avalia que a Revolução dos Cravos foi recebida como "uma simples mudança de cenários que não alteraria o pacatíssimo e delicioso viver à beira-mar plantado, nem alteraria em nada a imagem que os portugueses faziam de si mesmos", não afastando o problemático "nacionalismo chauvinista, paranóico e irrealista, [...]." (Lourenço, 1989: 64 e 66).

Com base nessas premissas, nosso objetivo específico aqui é mostrar como se dá nos dois romances de Saramago a representação da mentalidade portuguesa sob

3 “A liberdade de expressão é regulamentada pelo Decreto-Lei n²2469, de 11 de Abril de 1933, para que se pudesse «impedir a perversão da opinião pública na sua função de força social e que deverá ser exercida por forma a defendê-la de todos os factores que a desorientem contra a verdade, a justiça, a moral, a boa administração e o bem comum, e evitar que sejam atacados os princípios fundamentais da organização da sociedade», como referia 0 artigo $3^{\circ}$ do citado diploma." (SILVA, 2009: 3112-3113). 
o jugo dessa tensão político-jornalística. Sendo assim, muito além de apenas reproduzir as notas jornalísticas do passado português recente, Saramago tenta captar seu discurso em sua disposição tendenciosa e fictícia, repercutindo nos romances quase como uma encenação. Esse dispositivo é que fundamenta, segundo ele, os processos de seleção, elaboração, formulação e distribuição das notícias, multiplicando ao infinito a abordagem dos acontecimentos (Saramago, 2014).

No romance 0 ano da morte de Ricardo Reis, há várias linhas dedicadas à crítica das notícias veiculadas pelo jornal 0 Século, que por sua vez apoiava a ditadura. 0 romance tem Ricardo Reis como seu protagonista: além de poeta, trata-se de um leitor assíduo desse e de todos os meios de comunicação que "adotavam uma postura pró-Salazar, apoiando, além do ditador português, todos os regimes totalitários em voga na Europa da década de 30." (Matias; Roani, 2007: 116-117).

Atuando na contramão desse discurso dissimulado, a representação literária construída nesse romance de Saramago empreende um mecanismo alegórico para o tratamento do jornalismo salazarista, alegoria essa que implode e desdobra a totalidade legitimadora das notícias forjadas. Assim, a alegoria passa a revelar um outro lado da história da imprensa, remetendo o seu leitor ao que antes se encontrava perversamente oculto nos meios de comunicação. Essas revelações ocorrem através do narrador ou de outros personagens que fazem parte do círculo de vivência de Ricardo Reis.

A respeito desse mecanismo alegórico, Walter Benjamin dissera que é fundamental para manter parte da integridade de uma época ou de uma sociedade, denunciando ao mesmo tempo uma história representada de forma perversa e que serve unicamente aos interesses do poder instituído. Para esse pensador alemão, a verdadeira história deve ser acompanhada por essa alegoria que a segue e subjaz nos interstícios que o discurso factual deixa em aberto (Benjamin, 1994).

Em José Saramago, a soma dos elementos alegóricos é o resultado do cruzamento do seu engajamento com "um tratamento mais lírico na linguagem" (Thimóteo, 2010: 8). Nesse cruzamento, a alegoria sustenta o interesse social do escritor e percorre literariamente a história do quotidiano e da mentalidade portuguesa em épocas distintas, mostrando alto poder de expressar os imaginários sociais e políticos, institucionalizados pela mídia impressa.

As imagens hiperbólicas, as antíteses como forma de balancear os lados da questão, o constante construir do texto para que se enxerguem as distinções nas similaridades, ou as semelhanças nas diferenças é o modus operandi do cronista. (Thimóteo, 2010: 6)

Nesse modus operandi, Saramago perpassa pelas fronteiras do ficcional e do não ficcional, norteando sua produção textual através dos diferentes graus heurísticos mediados pelo discurso ficcional. Diante dessa estratégia discursiva, o escritor adquire uma narrativa múltipla e reconfigurativa, cujo pano de fundo se encerra numa reflexão sobre a ação e a inação dos portugueses ante o espetáculo imaginário efetivado por sua mídia em períodos divergentes da história. 0 recorte fragmentado dessa exposição é tratado tanto no âmbito do indivíduo quanto no da coletividade.

Como Maria Alzira Seixo salienta, em várias obras literárias de Saramago, como Deste mundo e do outro e A bagagem do viajante, notamos a presença das crônicas 
que se propõem, na tessitura romanesca, como um jogo de omissões e "emissões de uma opinião que se pretende genérica, coletiva, a dos leitores que, na resposta crítica aos acontecimentos do tempo, o jornalista procura representar." (SEIXO, 1999: 17).

A intertextualidade do discurso cronístico de Saramago acaba por projetar a sua forma romanesca de reorientação semântica diante desses fatores sociopolíticos. Desse modo, a presença das notícias jornalísticas em 0 ano da morte de Ricardo Reis suscita planos alegóricos denunciativos, pois o narrador e alguns personagens desmascaram o comportamento conformado do público leitor desses jornais, estes que se apresentam como Ricardo Reis, ludibriados pela publicidade do governo salazarista.

Tal conformação revela-se como a mentalidade histórica verossímil de uma comunidade específica de leitores cuja representação é norteada pelo surgimento frequente de fragmentos das notícias de 1936, especialmente do jornal lisboeta O Século, que de jornal republicano se tornou um veículo de defesa da ditadura: “[...], são estas as notícias da minha terra natal, e dizem, 0 chefe do Estado inaugurou a exposição de homenagem a Mouzinho de Albuquerque na Agência Geral das Colónias, não se podem dispensar as imperiais comemorações nem esquecer as figuras imperiais, [...]." (Saramago, 1988: 25).

Por meio das notícias repetitivas dos jornais, o romancista nos apresenta um panorama breve da história da imprensa portuguesa conservadora da década de 1930, revelando por meio desse panorama a ascensão do regime salazarista e a consequente manipulação das notícias. Nesse quadro editorial opressivo, busca-se recompor dentro do romance esse momento conturbado pela ascensão de regimes totalitários por toda a Europa, como o salazarismo, o nazismo e o fascismo.

Ao mesmo tempo que explora essa senda histórica, o romance 0 Ano da Morte de Ricardo Reis direciona o leitor ao mundo de Fernando Pessoa e faz reviver, no seu protagonista, um de seus heterônimos mais conhecidos: Ricardo Reis. Sem dúvida Saramago valeu-se da essência heteronímica de Fernando Pessoa, uma vez que o poeta personalizou Ricardo Reis com um caráter evidente de indiferença, como vemos caracterizado nas odes: "[...] só na ilusão da liberdade / A liberdade existe" (Pessoa, 2013: 16).

Essa indiferenciação se revela no ato de se isolar dos outros e procurar apenas, dentro de uma sobriedade individualista, o que the agrada e apraz. Desse modo, "Ricardo Reis mostra-se um poeta sensacionista equilibrado, que intelectualiza suas emoções a todo instante" (Quadros, 2008: 101). Essa postura quase estoica de desencantamento do mundo, principalmente dos interesses políticos, faz de Ricardo Reis um personagem apropriado para José Saramago abordar o tema da alienação na reconstituição de uma Lisboa sob o controle informacional dos jornais salazaristas.

0 heterônimo Ricardo Reis é um médico residente no Brasil, onde possui sua própria clínica. No romance, somos informados do seu retorno a Portugal no ano de 1935, ano em que Fernando Pessoa morre. 0 personagem é trazido de volta à pátria após 16 anos e já se depara com o próprio fantasma do seu próprio criador e com Lídia, uma das musas de suas odes. Notaremos que configurar a independência em relação ao seu poeta criador proporciona certa autonomia a Ricardo Reis, que de heterónimo torna-se uma personagem do romance de Saramago.

Isso não significa, porém, que sua poética anterior seja totalmente perdida e desintegrada, muitos aspectos criados por Pessoa serão reaproveitados no texto 
saramaguiano. A manutenção dessa característica de indiferença e alheamento, por exemplo, é importante para o romancista abordar o mundo possível dos leitores dos jornais salazaristas, bem como a política censória implantada. Assim, diante desse caráter de indiferença, Ricardo Reis é caracterizado como um personagem conformado com a situação do país, defendendo a todo o instante o ponto de vista jornalístico conservador.

Contudo, a desconstrução desse discurso opressor é efetivada a partir da intromissão dialógica ${ }^{4}$ dos comentários e relativizações que o narrador em terceira pessoa e os personagens Fernando Pessoa e Lídia fazem acerca dessas notícias que 0 personagem Ricardo Reis consome apenas de forma contemplativa. Essa perspectiva dialógica pode ser observada no seguinte diálogo entre Pessoa e Reis:

Ora Reis, são artigos encomendados pela propaganda, pagos com o dinheiro do contribuinte, lembro-me de ouvir dizer, Mas olhe que a imprensa de cá também se derrete em louvações, pega-se num jornal e fica-se logo a saber que este povo português é o mais próspero e feliz da terra, ou está para muito breve, e que as outras nações só terão a ganhar se aprenderem connosco, 0 vento sopra desse lado, Pelo que Ihes estou a ouvir, você não acredita muito nos jornais, Costumava lê-los, Diz essas palavras num tom que parece de resignação, [...]. (Saramago, 1988: 283)

Nesse dialogismo de discursos e opiniões, chama a atenção também o modo crítico e irônico como o narrador se apresenta em algumas partes do texto, descrevendo Reis como um simples "[...] espectador do espetáculo do mundo, sábio se isso for sabedoria, alheio e indiferente por educação e atitude" (Saramago, 1988: 90). 0 aspecto poético de contemplação e de distanciamento do mundo, traduz claramente o comportamento mental desse e outros personagens históricos da época.

Todavia, mesmo sendo Ricardo Reis o protagonista do romance, de modo algum a obra é reduzida à representação do discurso jornalístico opressor, primeiro porque efetiva uma dimensão crítica pelo efeito rotineiro, jocoso e pouco reflexivo das notícias que são lidas por esse protagonista. Segundo, porque a alegoria que a obra pressupõe é semelhante àquela designada por Benjamin, que instaura ações e identidades sem deixar de provocar no texto sua transformação com a abertura de espaços dialógicos para assimilar outras formas e outros pontos de vista.

Esse dialogismo nos sensibiliza para o fato de Reis se satisfazer acriticamente com a leitura dos acontecimentos do mundo noticiado pelo jornal 0 Século e outros veículos de comunicação que seguem a mesma linha política: "Ricardo Reis é sim este homem que está lendo o jornal com os seus próprios olhos abertos e vivos, médico, de quarenta e oito anos de idade, [...]." (Saramago, 1988: 32).

Ele mantém-se isolado em seu quarto de hotel e, mais tarde, em sua própria casa no Alto de Santa Catarina, espécie de local de reclusão do poeta: 0 que avistava pela sua janela e pelas páginas dos jornais contemplavam seu desejo de manter-se a par da verdade dos fatos:

4 Essa perspectiva é aqui entendida segundo os preceitos de Mikhail Bakhtin, que ressalta que 0 desenvolvimento do romance consiste em "um aprofundamento do diálogo, do seu alargamento e refinamento" (BAKHTIN, 1993: 105), pois é a partir dele que a modernidade rompe a unidade valorativa do enredo tradicional e abre o leque competitivo e diversificado das representações discursivas do sujeito. 
Vai Ricardo Reis aos jornais, vai onde sempre terá de ir quem das coisas do mundo passado quiser saber, aqui no Bairro Alto onde o mundo passou, aqui onde deixou rasto de seu pé, pegadas, ramos partidos, folha pisadas, letras, notícias, é o que do mundo resta, o outro resto é a parte de invenção necessária para que do dito mundo possa também ficar um rosto, um olhar, um sorriso, uma agonia [...]. (Saramago, 1988: 31)

Ao longo da narrativa, o narrador nos mostra a possibilidade de existência de pessoas como Ricardo Reis, que se limitam a aceitar e a reproduzir o discurso daquilo que leem, sem considerarem os interesses e as ideologias implícitas no consteúdo noticiado: "[Reis] Não chega a inquietar-se com as notícias que lhe chegam do mundo, talvez por temperamento, talvez por acreditar no senso comum [...]." (Saramago, 1988: 380).

Em contrapartida, a intromissão do narrador relativiza a dimensão noticiosa veiculada pela ditadura. Ele revela aos seus leitores que o discurso jornalístico não pode ser tomado como verdade absoluta, visto que até a descrição do quadro social português era totalmente alterada pelos jornais. As notícias eram suscetíveis a uma censura impiedosa, que cuidava unicamente de lisonjear o regime salazarista e a população subjugada a ela: "Dizem [...] os jornais, de cá, que uma grande parte do país tem colhido os melhores e mais abundantes frutos de uma administração e ordem pública modelares, [...]." (Saramago, 1988: 82).

Porém, é mirando as lacunas dessa farsa jornalística que é preciso compreender também o campo de ação e caracterização crítica de personagens como Lídia. Enquanto nas odes pessoanas ela tem somente o papel de musa platonicamente amada, no romance sua função de camareira de hotel é construída com cenas mais críticas em que se revela a proliferação e o controle político sobre o discurso jornalístico: "Você, Ricardo, nunca foi irônico, [...]." (Saramago, 1988: 280).

Com um discurso acusativo, Lídia é a representação mental de uma classe social trabalhadora geralmente marginalizada pela historiografia oficial, mas muitas vezes consciente das dissimulações políticas e publicitárias do jornalismo do regime. 0 ponto de vista ideológico de Lídia revela a agonia e a crítica dos empregados ao governo, posicionamento diferente de Ricardo Reis e dos jornais que o rodeavam.

No romance, Lídia obtém tal poder crítico especificamente por influência de seu irmão Daniel, que por sua vez fazia parte de um corpo comunista da marinha lusitana. Por uma questão crítica, portanto, a narrativa enfatiza a voz dos excluídos, contribuindo para uma visão diferente do passado ditatorial que a ficção resgata e reescreve dialogicamente.

Numa das cenas amorosas entre Lídia e Reis, ela, com carinhosa ironia, tenta alertá-lo para o mundo de forma mais crítica. As intervenções de Lídia ocorrem no sentido de fazê-lo deixar o lugar de mero espectador dos jornais e de poeta confinado no Alto de Santa Catarina:

Não é do senhor doutor que eu duvido, o que meu irmão diz é que não se deve fazer sempre fé no que os jornais escrevem, Eu não posso ir a Espanha ver o que se passa, tenho de acreditar que é verdade o que eles me dizem, um jornal não pode mentir, seria o maior pecado do mundo, 0 senhor doutor é uma pessoa ins- 
truída, eu sou quase uma analfabeta, mas uma coisa eu aprendi, é que as verdades são muitas e estão umas contra as outras [...] o senhor doutor fala-me sempre com as palavras dos jornais. (Saramago, 1988: 387-388)

No excerto acima, Lídia chama atenção para o fato de que é preciso relativizar as notícias divulgadas pela imprensa. Ainda segundo ela, Reis falava "sempre com as palavras dos jornais", trecho que revela fortemente a crítica de Saramago com relação à alienação e ao conformismo possível dos leitores de jornais da época histórica em que viviam os personagens.

Nesse sentido, voltamos ao personagem principal, para dizer que, conforme aponta Gerson Roani, esse intertexto com o heterónimo de Pessoa não revela apenas uma simples reprodução, um transporte absoluto de suas ações na poesia para as linhas do romance. Cabe salientar que o ficcionista português se aproveita criativamente do heterônimo, explorando novos aspectos que 0 aproximam de um personagem dotado de memória histórica, mesmo quando essa memória é caracterizada por uma mentalidade de indiferenciação do personagem com o próprio mundo sociopolítico que o cerca:

[...] a ficha biográfica legada por Pessoa acerca de sua constituição revela uma ausência de memória histórica. [...]. Na esteira dessa tentativa de "preenchimento", de dar uma compleição carnal e moral a Ricardo Reis, o romance reverbera de um realismo descritivo que dá à narrativa uma conformação verossímil em relação ao tempo evocado. (Roani, 2001: 134-135)

Enquanto no romance o universo de ação de Ricardo Reis ocorre no tempo histórico e psicológico da censura, em Pessoa, por outro lado, Ricardo Reis tem por aspecto isolar-se da própria história, como podemos observar na própria fala que o poeta dirige a seu heterônimo em uma das linhas do romance: "Você, Reis, tem sina de andar a fugir das revoluções, em mil novecentos e dezenove foi para o Brasil por causa de uma que falhou, agora foge do Brasil por causa de outra que, provavelmente, falhou também, [...]." (Saramago, 1988: 78).

Diante dessa indiferença duplamente abordada, é mais do que necessário apontar que:

a presença da história, no romance, não pode ser considerado, portanto, um mero pano de fundo a enquadrar as ações narrativas desenvolvidas pela personagem, mas o âmbito privilegiado, no qual todas as referências, principalmente as jornalísticas, suscitadas pelo romance se cruzam, se espelham, duelam entre si e se abrem em muitas perspectivas. Tal é a intencionalidade de colocar a presença da história como núcleo estruturante [...] (Roani, 2001: 133).

Nesse jogo apropriativo de contextos e discursos, Saramago tece um Ricardo Reis diferente do poeta criado por Fernando Pessoa. Na obra romanesca, o seu estado apenas contemplativo é invertido pelo tom jocoso e ingênuo em que as notícias quotidianas são tratadas, ou seja, Reis é caracterizado por outros ângulos em que se sobressai a mentalidade conservadora e conformista desse contexto 
histórico. Tal representação é de suma importância para a abordagem da história do jornalismo português, pois possibilita reviver de forma criativa e questionadora o ponto de vista jornalístico na época do regime, evidenciando a apropriação do jornal como máquina eleitoreira do governo salazarista.

0 romance de Saramago ganha ainda mais pertinência hoje pelo fato de que, mesmo com a implantação do PREC (Processo Revolucionário Em Curso) após 1974, que visava proteger a liberdade de imprensa de qualquer tipo de censura e garantir a livre concorrência no setor midiático, os jornais, depois o rádio e a televisão, sempre continuaram muito suscetíveis ao controle do poder político.

Como aponta Diogo José da Rocha Ribeiro, mesmo após a Revolução dos Cravos, "a gula dos governos levou-os a utilizar sempre os meios de comunicação do Estado como instrumento ao serviço da sua política, sendo esta perspectiva partilhada por todos os governos e todos os partidos" (Ribeiro, 2012: 11). A privatização dos jornais e televisões estatais no fim da década de 1980 e 90 não anulou os constrangimentos políticos sobre a mídia portuguesa", fazendo com que "a influência que 0 poder econômico passou a exercer sobre o trabalho jornalístico acaba por ser confundido com as influências típicas do contexto político anterior" (Ribeiro, 2012:11).

Essa contínua pressão dissimulada pelos jornais é bastante evidente, visto que as elites empresariais estiveram sempre entrelaçadas com as elites políticas, em uma partilha íntima de interesses ${ }^{6}$. Vale ressaltar que mesmo na mídia mais recente, muitas emissoras e jornais optam por não transmitir um material jornalístico mais focado no interesse humano e no conhecimento das questões políticas, preferindo captar uma audiência focada em conteúdos triviais ou insólitos como fofocas entre artistas e reality shows, que podem chamar mais atenção e serem assimilados mais facilmente por uma população que se quer desatenta e desinteressada dos assuntos administrativos do seu país.

\section{A farsa COMUNicAtiva em A Jangada de PEDRA}

É nesse complicado contexto radiofônico e televisivo do jornalismo português que se revela o discurso noticioso em $A$ jangada de pedra. Nessa obra, os meios de comunicação eletrônicos e impressos se concentram num calamitoso acontecimento geológico ocorrido nos Pirenéus, em detrimento das polêmicas informações político-econômicas acerca da entrada de Portugal e Espanha na CEE (Comunidade Econômica Europeia), inclusão ocorrida em 1986, o mesmo ano da publicação do romance. Além de proliferarem os jornais com notícias espetaculares sobre 0 acidente geológico, muito se noticiava, de dentro e fora de Portugal, que as consequências

5 “Observa-se, por exemplo, uma coligação entre o Partido Social Democrata (PSD) e o Centro Democrático Social (CDS-PP), [...], que esteve recentemente envolvido em dois casos paradigmáticos: o cancelamento de um programa da Antena 1, depois de um jornalista ter tecido críticas às opções do executivo no âmbito do relacionamento com Angola (Público, 22 de Fevereiro de 2012); e pressões de um ministro sobre jornalistas do Público, para que não publicassem matérias sensíveis sobre o governo (Público, 25 de Maio de 2012)." (RIBEIRO, 2012: 11).

6 “Num artigo publicado em Fevereiro de 2002 no jornal Público, o jornalista e investigador Mário Mesquita evoca casos de jornalistas «de referência» com trajectos entre 0 jornalismo e a política: "Após o 25 de Abril, diversos jornalistas transitaram para o Parlamento»." (SERRANO, 2006: 70). 
da adesão à CEE seriam extremamente importantes para o país, especificamente na consolidação da democracia e economia portuguesas.

0 próprio Saramago publicou na época muitas crônicas jornalísticas criticando essa adesão do país à CEE. Ademais, em A jangada de pedra, Saramago não hesitou em argumentar contra tal medida do governo português, concluindo que tanto a europeização da cultura lusa quanto a desnacionalização da economia do país não eram a fórmula mais satisfatória para Portugal responder às suas necessidades imediatas de modernização, democratização e reinserção na economia mundial.

No romance $A$ jangada de pedra, o conformismo midiático é colocado de forma questionadora, pois é abordada como um jornalismo que foi acrítico perante a adesão de Portugal à União Europeia, o que denuncia a apropriação empresarial dos meios de comunicação e o ludibriamento da população diante de tais questões governamentais. É essa apropriação noticiosa e ludibriada dos meios de comunicação que possibilita a intromissão de elementos fantásticos no texto, direcionando a representação do estado mental da população.

Ao criar a alegoria de uma viagem fantástica da península Ibérica por mares atlânticos, temos a representação de um processo que distancia da Europa o espaço identitário português. Esse distanciamento pode ser observado explicitamente no trecho a seguir:

[...] segundo as últimas medições conhecidas ia em cerca de duzentos quilómetros o afastamento, se viu sacudida, dos alicerces ao telhado, por uma convulsão de natureza psicológica e social que dramaticamente pôs em mortal perigo a sua identidade, negada, nesse decisivo momento, em seus fundamentos particulares e intrínsecos, as nacionalidades, tão laboriosamente formadas ao longo de séculos e séculos. (Saramago, 1996: 151)

0 fato de Portugal e Espanha se separarem do continente mostra nitidamente uma interferência do espaço nas relações sociopolíticas e culturais, uma crítica à relação da Península Ibérica com a Europa no exato momento de publicação do romance no ano de 1986. Na verdade, como alerta Eduardo Lourenço, no ensaio intitulado Nós e a Europa, esse sentimento de marginalidade e vazio de Portugal em relação à Europa é antigo: "o mistério da nossa identidade, [...] está precisamente relacionado com a nossa pequenez e com a vontade de separação do resto da Ibéria que conferiu ao povo português um outro destino, um destino menos europeu" (Lourenço, 1988: 18).

Essa posição crítica é figurada no romance como uma dissimulação imaginária existente entre a península e a parte continental europeia: "Sabe, a Europa é longe como um raio, fica lá para o fim do mundo." (Saramago, 1996: 151). É preciso, portanto, nos atentarmos para essa elaborada alegoria espetacular e fantástica que configura o romance, pois ela não se restringe apenas à representação do afastamento físico da península. Veremos que esse afastamento é apenas um modo de balançar o pensamento dos portugueses, alertá-los para um outro afastamento que é aquela do aspecto inteligível da população perante o que se passa no curso sociopolítico do país.

Enquanto os meios de comunicação, pelos quaais a maioria da população se mantinha informada, se focam na emissão de notícias sobre o chocante desprendimento geológico e suas possíveis causas insólitas, Portugal assina acordos com 
a CEE, iniciando o processo de desnacionalização de sua economia: "[...] por cada segundo são dois centímetros e picos, comentou José Anaiço rápido em cálculo mental, não pôde chegar às décimas e centésimas, Joaquim Sassa pedia-Ihe que se calasse, queria ouvir o locutor, e valia a pena, [...]." (Saramago, 1996: 45).

A omissão sobre a atualidade política e econômica do país gerou, no romance, uma impactante falta de lucidez por parte da população:

"A potência imaginativa dos jornalistas encontrou vazão quase exclusiva na armação estentórea dos títulos, porquanto os segredos da deslocação geológica, melhor dizendo, o enigma tectônico, continuavam por desvendar, tão indecifráveis [desde o] primeiro dia." (Saramago, 1996: 284).

Similar dissimulação pode ser encontrada nos periódicos portugueses entre as opiniões otimistas que só veem benefícios na integração do país à CEE. Em primeiro lugar, porque teria permitido consolidar a democracia portuguesa e, em segundo, porque serviu de "alavanca do desenvolvimento econômico, por reduzir a taxa de inflação para níveis históricos e a melhoria das condições de vida dos portugueses." (Sousa, 2000: 194).

Contudo, nenhuma dessas condições terá impedido que a Balança Comercial Portuguesa continuasse negativa. Um artigo publicado em 24 de maio de 2014 no Jornal de Letras, Artes e Ideias, diz que Portugal é hoje, dentro da Zona Euro, "o país, onde se regista um dos maiores consensos - tanto na opinião pública como nos partidos políticos e nas forças sociais - acerca da necessidade de prosseguir no rumo europeu do país." (Marques, 2014, s/p). Isso significa que muitos não sabem ou esquecem, ao emitir tal opinião, das várias fragilidades estruturais que o país ainda apresenta ${ }^{7}$.

Ao publicar seu romance no ano de 1986, José Saramago não conhecia o futuro da União Europeia, mas sua obra já apontava algumas falhas futuras que seu país certamente viveria com essa adesão. Trinta anos após a publicação de $A$ jangada de Pedra, a frágil unidade da União Europeia surge ameaçada como nunca. Alguns países que integram esse bloco como a Grécia e Portugal, que esperavam obter certa hegemonia e estabilidade, apresentam problemas crescentes de ordem econômica e social. Trata-se especialmente da situação geral de países europeus designados como periféricos nessa política eurocêntrica.

0 que temos como resultado dessa adesão econômica é que ela não significou nada mais do que a devastação comedida dos países periféricos, esses que são a maioria da CEE e que estão sendo prejudicados socioeconomicamente em benefício do capital financeiro controlado por países detentores de indústrias, empresas e capital como a França e, principalmente, a Alemanha ${ }^{8}$.

7 "A economia portuguesa, apesar de ter acusado, na última década, um salto qualitativo importante, no sentido da convergência real com os restantes membros da UE, continua marcada por fracos padrões de especialização [...]; as reformas necessárias continuam a ser feitas, apenas, em função dos tempos e das exigências impostas pela UE; a taxa de analfabetismo de Portugal, 9\% da população, mantém-se a mais elevada da Europa; por outro lado, os níveis de escolaridade e formação continuam muito baixos; perto de 2/3 da população registra menos de 10 anos de escolaridade; [....". (SOUSA, 2000: 197).

8 Foram empresas dos países considerados desenvolvidos desse grupo que "lucraram com a rede telefónica e energética estatais ou monopolizaram a renovação das frotas de táxis e eléctricos gregos, 
[...] encontrei-me de repente incluído na minoria privilegiada que conhece as razões profundas e autênticas por que a CEE nos quer no seu regaço. Revelo-as aqui em três definitivas palavras- porque somos atrasados. [...]. [No contrário] iríamos complicar o funcionamento das instituições, os europeus só quereriam os nossos produtos, e não suas economias arruinadas, e quanto à cultura, temos conversado: os nossos emigrantes, onde quer que estivessem, passariam a dar lições e a fazerem-se pagar bem por elas. Não é assim, e assim não será. A CEE quer-nos (ou faz parecer que nos quer) pela já dita razão: porque somos atrasados. [...], se não temos nada para vender à CEE, estamos nas melhores condições para tudo termos de comprar à CEE. (Saramago, 1999: 117).

Complementando essa crítica de Saramago, afirmamos que a unificação econômica proposta pela UE deu-se inicialmente com base no estabelecimento do domínio financeiro direto do imperialismo franco-alemão sobre um conjunto de países considerados economicamente díspares, que por sua vez renunciou a emissão de uma moeda própria, como também abdicou de muitas empresas estatais. Essa renúncia "permitiu uma poderosa expansão e fortalecimento do capitalismo franco-alemão, que aproveitou a época das "vacas gordas" para alargar e fortalecer o seu domínio comercial e industrial no mercado europeu periférico." (Alegria, 2010).

Assim como pode ser observado em suas crônicas jornalísticas, no romance Saramago não deixou de se posicionar sobre tal estratégia imperialista da UE, apresentando o posicionamento crítico de suas crônicas por entre as linhas de $A$ jangada de pedra. Compare, por exemplo, um trecho da Jangada com um excerto jornalístico de Saramago, e veja como ambos se dirigem similarmente ao mesmo tema:

[...] esses governos [europeus], em vez de nos apoiarem, como seria demonstração de elementar humanidade e duma consciência cultural efectivamente europeia, decidiram tornar-nos bodes expiatórios das suas dificuldades internas. (Saramago, 1996: 161)

[...] rejeito a denominada «construção europeia» por aquilo que vejo estar a ser a constituição premeditada de um novo "sacro império germânico», com objectivos hegemónicos que só nos parecem diferentes dos do passado porque tiveram a habilidade de apresentar-se disfarçados sob roupagens de uma falsa consensualidade que finge ignorar as contradições subjacentes, [...]. (Saramago, 1995: 55)

Apresentadas as semelhanças do tom crítico de cada um dos excertos, não temos dúvidas quanto ao fato de que a interrupção crítica do narrador em $A$ jangada

recorrendo a subornos generalizados, como no caso da alemã Siemens. Durante este período, a economia grega foi fortemente desnacionalizada, com a companhia telefónica OTE controlada pela Deutsche Telecom, as linhas aéreas nacionais privatizadas e até os portos vendidos à empresa chinesa Cosco. A banca e os grandes empresários gregos somaram-se com entusiasmo a uma festa que agravou a desigualdade social num dos países europeus onde esta era mais acentuada (80 grandes armadores possuem um património equivalente a todo o PIB grego)" (ALEGRIA, 2010: s/p). 
de pedra implica na integração literária das críticas que fazia o José Saramago jornalista. É possível perceber a posição ideológica do narrador do romance e inferir que suas opiniões estão claramente associadas ao que escreveu Saramago nas crônicas jornalísticas a respeito da integração político-econômica em questão.

Na contramão desse narrador crítico e dessas interferências que denunciam a dissimulação das notícias, não seria a investigação maciça das causas da grande fenda uma alegoria da perversidade da mídia e da ingenuidade da população portuguesa frente à sacramentação dos interesses políticos da União Europeia? Muitos aspectos da obra apontam para essa possibilidade de leitura, como nas diversas intromissões do narrador: "A nós... compete-nos, [...], rejeitar energicamente as pressões e as ingerências de toda a ordem e de qualquer proveniência, proclamando à face do mundo que apenas nos deixaremos guiar pelo interesse nacional [...]." (Saramago, 1996: 161).

Diluída a crítica jornalística no romance, Saramago nos proporciona desvios dos discursos imperialistas da UE, construindo um narrador análogo a sua crônica jornalística para questionar ininterruptamente o sensacionalismo no entorno da geológica fenda, estratégia típica de uma mídia que obtém vantagens econômicas e políticas do setor empresarial.

Nesse confronto, ganha força a tensão alegórica entre os casos insólitos e geológicos que chamam toda atenção nas reportagens e nas percepções individuais dos personagens protagonistas, explorando assim o caráter imaginário alienante de grande parcela da população. Portanto, a narrativa desenvolve-se na alegoria exaustiva de um discurso jornalístico trivial que silencia os problemas político-econômicos ressaltados: "Mal desembarcaram, os jornalistas vão indagar como foi que isto se deu, e recolhem todos a mesma história, com algumas elaboradas variantes, que a sua própria imaginação ainda mais irá enriquecer, [...]." (Saramago, 1996: 25).

Aliás, é por meio da imprensa que as personagens principais e toda a população se informam sobre o estranho movimento da península. É, por exemplo, por meio da televisão que Joaquim Sassa fica sabendo que a terra treme sob os pés do farmacêutico espanhol Pedro Orce, como é pelo rádio do automóvel de Sassa que toma ele próprio conhecimento de que está sendo procurado pelas autoridades.

É também por meio dos veículos de comunicação que Joana Carda fica sabendo dos casos sobrenaturais de José Anaiço, Joaquim Sassa e Pedro Orce' ${ }^{9}$ Iocalizados no Hotel Bragança (o mesmo em que trabalhava Lídia e se hospedara Ricardo Reis). Enfim, a importância do papel desempenhado pela imprensa é tal, que seu

9 "Os cinco personagens - três homens, duas mulheres, que mais tarde serão acompanhados por um cão - não se conhecem, sequer suspeitam do que está ocorrendo quando se deparam cada um com um estranho fenômeno que lhes desperta a atenção. Joana Carda risca o chão com uma vara de negriIho e o traçado jamais desaparece; José Anaiço é subitamente seguido por um bando de estorninhos por onde quer que vá; Joaquim Sassa em uma praia lança uma pesada pedra ao mar que, contrariando as leis da física, continua pulando sobre a água, malgrado seu peso; Pedro Orce sente subitamente sob seus pés um tremor contínuo que os sismógrafos e sofisticados aparelhos são incapazes de detectar; Maria Guavaira, para ocupar seu tempo de mulher solitária, começa a desfazer uma meia desfiando a lã que não cessa seu desenrolar. Enquanto isso se passa, o cão Ardent escolhe as regiões infernais quando instintivamente salta da fronteira da França para a Espanha no momento em que se torna o único a testemunhar o aparecimento de uma inexplicável fenda abaixo de suas patas." (AMORIM, 2011: 113). 
discurso é vital para a representação crítica desse plano alegórico mergulhado nas dissimulações midiáticas.

Portanto, em A Jangada de Pedra, critica-se a entrada de Portugal e Espanha na Comunidade Econômica Europeia no ano de 1986, e mostra-se, sobretudo, a presença de uma forte omissão midiática de informações sobre essa entrada. No lado obscuro do forjamento e da omissão das notícias, vibra um conteúdo mais reflexivo que orientaria melhor a população sobre as mudanças que estavam, na vida real, acontecendo.

Enquanto o espetáculo da fenda é mostrado em transmissão ao vivo pelo rádio e pela televisão, prevalece 0 jornalismo tendencioso e a desatenção da população. Desse vazio reflexivo, pelo menos um apontamento crítico e concreto deve ser ressaltado no romance: o de que a navegação sem rumo da península, causa de tantas dissimulações jornalísticas, proporciona ao menos um momento de reconstrução do olhar na relação de Portugal com o velho continente.

Assim observamos na fala irônica do personagem Roque Lozano, personagem que viajava rumo aos Pirinéus para averiguar os impactos da fenda: "Provavelmente, quando chegar lá, já não [verei] a Europa. Se eu a não vir, é porque ela nunca existiu, [...]." (Saramago, 1996: 67). A visão de que a Europa nunca existiu oferece ao leitor uma problematização identitária sem igual, uma sugestão de remodelamento dos valores socioculturais da nação.

Na parte final do romance, as mulheres grávidas da ilha Ibérica e a imagem da vara de negrilho de Joana Carda, que subitamente enverdece, apontam simbolicamente para esse remodelamento nacional de forma fértil. Com uma ferrenha crítica ao infantil europeísmo decorrente da má informação, o romance subverte a concepção dissimulada, neoliberal e disciplinar proliferada pelos meios de comunicação.

\section{Considerações finais}

Diante dessa eminente continuação da materia jornalística na literatura de Saramago, concluímos com a reflexão de Maria Alzira Seixo ao dizer que há um estilo do escritor que pode ser encontrado em todo seu conjunto textual: há "uma certa coincidência de atitude entre a crônica e o poema lírico; [...]." (Seixo, 1999: 17). É como se entre a prosa cadenciada e a manipulação das palavras, Saramago permita entrever menções estéticas e políticas subentendidas tanto nas narrativas quanto nas crônicas.

Diante de todas essas considerações feitas até aqui acerca dos impactos do jornalismo na obra romanesca de Saramago, presumimos que seu perfil como jornalista "não difere, obviamente, do perfil do escritor e do político, todos eles coexistentes num homem de convicções firmes, de grande frontalidade, defensor dos fracos e um lutador incansável pela evolução da humanidade." (Gonçalves, 2010)

Com a análise dos dois romances em questão, ficam evidentes os conflitos ideológicos e humanistas expostos por José Saramago, especificamente na relação da população com a mídia empresarial e conservadora vigente no seu país. Na então crescente disseminação do sensacionalismo e com a tendência de tornar as peculiaridades da vida privada relevantes ao conhecimento social, o entretenimento e os shows espetaculares têm espaço cada vez mais garantido nos meios de comunicação, tendência essa que certamente provocou grande preocupação por parte do escritor português. 


\section{REFERÊNCIAS BIBLIOGRÁFICAS}

Aguiar, Marta (2014). José Saramago e os jornais: os anos de 1968 a 1975. Dissertação da ESCS, Lisboa.

Alegria, F. (2015). A crise grega e a União Europeia. In: (http://www.mas.org.pt) (Acessado em 01/02/2015).

Amorim, C. (2011). Nas fissuras da península e do sujeito - A jangada de pedra de José Saramago. Ipotesi. Juiz de Fora, v. 15, n. 1: 111-118.

Benjamin, Walter (1994). Magia e técnica, arte e política: ensaios sobre literatura e história da cultura. $7^{\mathrm{a}}$ ed. Tradução de Sérgio Paulo Rouanet. São Paulo: Brasiliense, v. I.

Benveniste, Émile (1976). Problemas de linguística geral. Tradução de Maria da Glória Novak e Luiza Neri. São Paulo: Ed. Nacional, EdUSP.

Castelhano, Glória \& Prata, Nair (2006). Ditadura, censura e o rádio: uma história de semelhanças entre Brasil e Portugal. In: (http://www.ufrgs.br/alcar/encontros-nacionais-1/40-encontro-2006-1) (Acessado em 20/12/2014).

Quadros, Denise de (2008). Afetos e estranhamento em 0 ano da morte de Ricardo Reis. Dissertação de Mestrado em Letras da Universidade Regional Integrada do Alto Uruguai e das Missões.

Gonçalves, João Alferes (2010). 0 jornalista José Saramago. In: (www.clubedejornalistas. $\mathrm{pt}$ ?p=2807) (Acessado em 14/07/2016).

Le Goff, Jaques (1999). Reflexões sobre a história (Entrevista de Francesco Maiello). Tradução de António José Pinto Ribeiro. Lisboa: edições 70.

Lepecki (1988), Maria Lúcia. Aspectos da narrativa de preocupação histórica em Portugal, hoje. Actas do Primeiro Congresso da Associação Internacional de Lusitanistas. Poitiers: 387-394.

Lopes, João Marques (2010). Saramago - Biografia. São Paulo: Leya.

Lourenço, Eduardo (1988). Nós e a Europa ou as duas razões. Lisboa: INCM.

Lourenço, Eduardo (1989). O Labirinto da Saudade. Psicanálise Mítica do Destino Português. 2. ${ }^{a}$ ed. Lisboa: Publicações Dom Quixote.

Marques, Viriato Soromenho (2014). Portugal na crise europeia. Jornal de Letras, Artes e Ideias. Lisboa, ed. 23, s/p.

Matias, Felipe dos Santos e Roani, Gerson Luiz (2007). Literatura e História em 0 ano da morte de Ricardo Reis, de José Saramago. Revista Alpha. Patos de Minas, v.8: 114-123.

Pessoa, Fernando (2013). Poesias Completas de Ricardo Reis. Lisboa: Editorial Caminho.

Real, Miguel (2012). O Romance Português Contemporâneo. Alfragide - Portugal: Editorial Caminho.

Ribeiro, Diogo José da Rocha (2012). 0 padrão ocidental do jornalismo político português: perceções dos jornalistas vis-à-vis o produto noticioso. Anais do ciclo de estudos em Ciências da Comunicação da Universidade do Porto. Porto: 4-17.

Roani, Gerson Luiz (2001). A história comanda o espetáculo do mundo: ficção, história e intertexto em "O ano da morte de Ricardo Reis" de José Saramago. Tese de Doutorado em Literatura Comparada pela Universidade Federal do Rio Grande do Sul.

Saramago, José (1988). 0 ano da Morte de Ricardo Reis. $2^{\mathrm{a}}$ ed. São Paulo: Companhia das Letras. 
Saramago, José (1996). A Jangada de Pedra. São Paulo; Rio de Janeiro: Editora Record.

Saramago, José (1995). Cadernos de Lanzarote I. São Paulo: Companhia das Letras.

Saramago, José (1999). Folhas Políticas (1976-1998). Lisboa: Editorial Caminho.

Saramago, José (2004). Ensaio sobre a lucidez. São Paulo: Companhia das Letras.

Saramago, José (2014). Os apontamentos. Porto: Porto Editora.

Serrano, Estrela (2006). A dimensão política do jornalismo. Comunicação \& Cultura. Lisboa, n. 2: 63-81.

Silva, Célia Maria Taborda da (2009). A comunicação como estratégia política da ditadura e da democracia. In: (www.sopcom.pt/cemat) (Acessado em 01/02/2015).

Seixo, Maria Alzira (1999). Lugares da ficção em José Saramago. Lisboa: INCM

Sousa, Fernando de (2000). Portugal e a União Européia. Revista brasileira de política internacional. São Paulo, v. 43, n. 2: 192-200.

Thimóteo, Saulo Gomes (2010). 0 'ars poetica' saramaguiano ou o cultivo da palavra. Nau Literária, Porto Alegre, v. 6, n. 1: pp. 1-13. 